\title{
Analysis of PDDikti Website User Satisfaction Using Webqual
}

\author{
Ony Ichsandrya ${ }^{1}$, and Erma Suryani ${ }^{2}$, \\ ${ }^{1}$ Department of Technology Management, Institut Teknologi Sepuluh Nopember, Surabaya \\ ${ }^{2}$ Department of Information Systems, Institut Teknologi Sepuluh Nopember, Surabaya \\ e-mail: erma@is.its.ac.id
}

\begin{abstract}
Based on Presidential Instruction of the Republic of Indonesia Number 3 of 2003 concerning National Policies and Strategies for E-Government Development, it is hoped that the government can provide services that are efficient, effective, transparent and accountable. One application is through the use of websites or websites in all government and non-government institutions, the Ministry of Research, Technology and Higher Education as one of the government institutions through its work unit, PUSDATIN, which provides services to stakeholders through the PDDikti website as an application of the development of E-Government initiated by the government. This research was conducted to identify PDDikti website service user satisfaction, namely by measuring user satisfaction using the modified Webqual 4.0 method and seeing the extent to which the intensity of use variables moderates the quality of service on PDDikti website service user satisfaction. The population and sample in this study are operators of Private Universities in East Java under the auspices of LLDIKTI Region VII, the statistical analysis used in this study is the statistical analysis of Partial Least Square (PLS), to see the extent of the influence of each variable used in this research. The final results expected from this study are, looking at the effect of service quality on user satisfaction, as well as looking at the moderating effect posed (positive / negative) by the Intensity Usage variable. This study resulted in the findings that the Variable Usual Quality, Information Quality, Services Interaction, and Visual Quality had a significant effect with a P-Value below 0.05 , as well as a positive moderating effect of the Usage Intensity Variable with a $P$ value of $<0.01$.
\end{abstract}

Keywords-Webqual 4.0, Intensity of Use, User Satisfaction, PDDikti Website.

\section{INTRODUCTION}

$\mathrm{T}$ HE Ministry of Technology Research and higher education as an agency that oversees and carries out the functions of higher education in Indonesia continues to innovate and develop internet-based information and communication technology (Website) as a function of its institution to provide information services to the public, this is done to minimize the occurrence misuse of information by certain parties which ultimately harm the community. The pdikti website can be accessed via https://pddikti.kemdikbud.go.id/.

This research aims to see the satisfaction of using the PDDikti.kemdikbud.go.id page because there is still no research that measures the level of user satisfaction of the PDDikti.kemdikbud.go.id page which is one of the channels owned by the Ministry of Research, Technology and Higher Education to provide effective and efficient services. This research was conducted to identify user satisfaction of PDDikti.kemdikbud.go.id website services, namely by

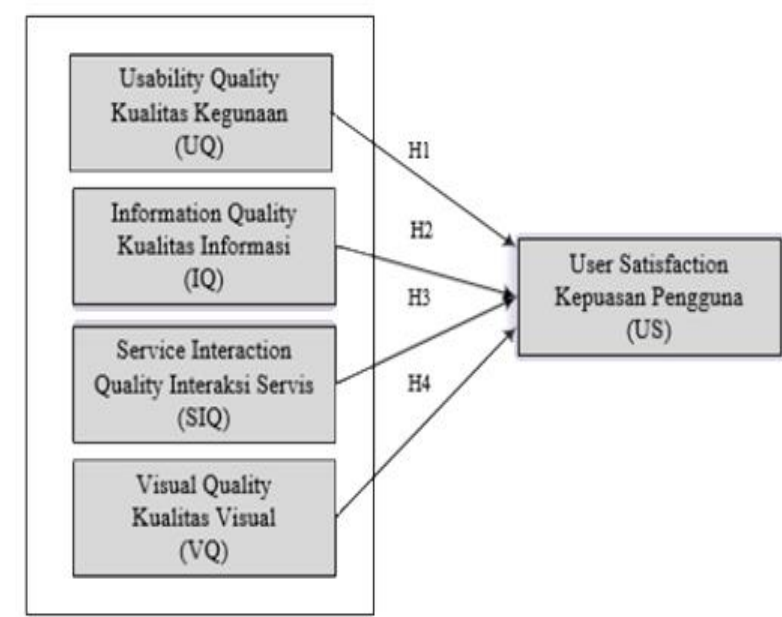

Figure 1. Warjiyono and Corie, 2018.

measuring user satisfaction using the modified Webqual 4.0 method and seeing to what extent the use intensity variable moderates service quality on user satisfaction of PDDikti website services.

\section{WEBQUAL 4.0}

WebQual 4.0 is a measuring tool for measuring the quality of websites based on research instruments. It can be categorized into four variables, namely usability, information quality, service interaction quality and overall impression.

This study will modify the concept of measuring webqual 4.0 by adding one category to the measurement concept of webqual 4.0 to test the effect of website service quality on user satisfaction levels and the intensity of website service use (Hasan, 2004 in Warjiyono and Corie, 2018).

The concept of webqual measurement in this study refers to previous research with four categories that affect the level of satisfaction in using website services can be seen in Figure 1 (Hasan, 2004) in Warjiyono and Corie, 2018.

Furthermore, the researcher develops a research model based on existing or previous research by adding the intensity of use variable as a moderating variable, and the model built by the researcher can be seen in Figure 2 .

\section{VALIDITY AND RELIABILITY TEST}

First, the results are analyzed for validity, which is to determine the test hypothesis and then test its validity. The proposed hypothesis:

1. H0: Item scores have a positive correlation with factor scores (total factor) 
The $6^{\text {th }}$ International Seminar on Science and Technology (ISST) 2020

July $25^{\text {th }}$ 2020, Institut Teknologi Sepuluh Nopember, Surabaya, Indonesia

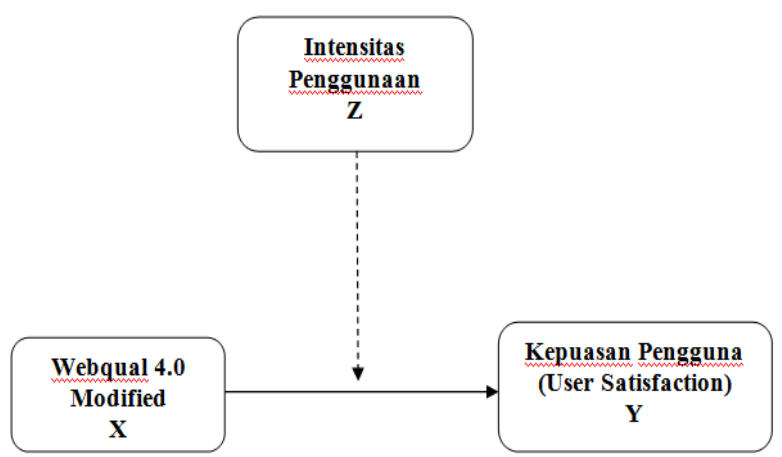

Figure 2. Research Model Relationship Between Webqual Variables on User Satisfaction Moderated by Intensity of Use.

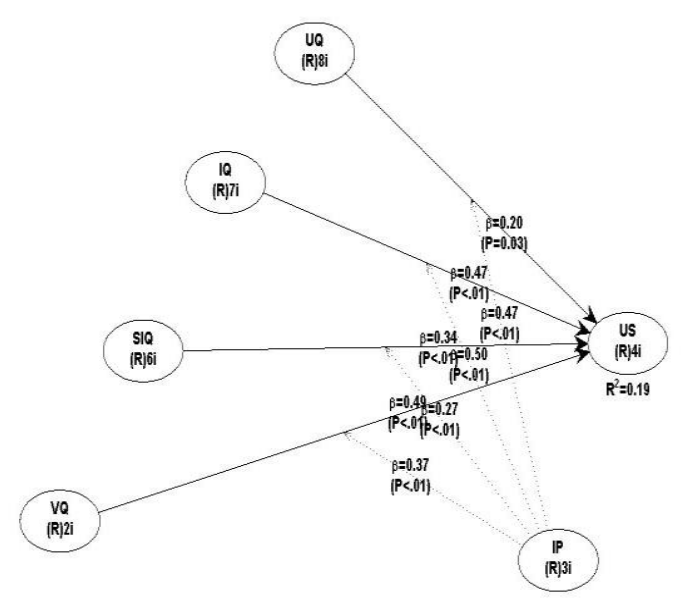

Figure 3. Structural Equation Diagram.

2. H1: Item scores are not positively correlated with factor scores

The consideration of acceptance / rejection of the hypothesis is to compare the Corrected Item-Total Correlation value which is stated as r-count with r-table. The basis for decision making, as follows:

1. r-count is positive and is greater than $r$-table ( $r$-count $>r-$ table), then the item or variable is valid.

2. r-count is negative and or r-count value <r-table, then the item or variable is invalid.

According to Sunaryo (2013), the reliability test was carried out by comparing the Cronbach's Alpha value with the r-table value, if the Cronbach's Alpha value is positive and greater than the r-table, then the instrument is reliable.

\section{RESEARCH RESULTS AND DISCUSSION}

\section{A. Convergent and Discriminant Validity}

Convergent validity can be seen from the average variance extracted (AVE) value, an indicator is considered valid if it has a correlation value above 0.7 , but for a correlation value of 0.5 to 0.6 it is still acceptable. This states that the model is valid and has met the validity requirements. Based on Table
1, it is known that the AVE (Average variances extracted) value in this study is an average above 0.5 . This proves that this research model has met the requirements or can be said to be valid (Ghozali, 2008)

\section{B. Reliability}

Reliability is used to see the feasibility level of each variable used in this study, the reliability of each indicator can be seen from the reliability of the composite or through Croncbach's alpha. Table 2, reliability range criteria according to Gliem and Gliem (2003).

Table 3 shows the reliability value measured by composite reliability and Croncbach's alpha. In the composite reliability value, the Usability Quality (UQ) variable reliability value was 0.883 including the high reliability category and the moderation model for the use intensity variable with the Usability Quality (UQ) variable of 0.991 , including the very high reliability category. The composite reliability value of the Information Quality (IQ) variable was 0.893 , including the high reliability category, the moderating model for the intensity of use, with the Information Quality (IQ) variable of 0.990 , including the very high reliability category. The composite reliability value of the Service Interaction Quality variable was 0.879 , including the high reliability category, the moderating model of the use intensity variable with the Service Interaction Quality variable of 0.987 , including the very high reliability category. The reliability value of the Visual Quality variable composite was 0.832 , including the high reliability category, the moderating model for the use intensity variable with the Visual Quality variable, 0.981, which was included in the very high reliability category.

On the reliability value as measured by Croncbach's alpha, the Usability Quality (UQ) variable reliability value is 0.843 , including the high reliability category and the moderation model for the intensity of use variable with the Usability Quality (UQ) variable of 0.990 , including the very high reliability category. The reliability value of the Composite Information Quality variable was 0.853 , including the high reliability category, the moderating model for the use intensity variable with the Information Quality variable, 0.989 , which was included in the very high reliability category. The composite reliability value of the Service Interaction Quality variable was 0.831, including the high reliability category, the moderating model of the use intensity variable with the Service Interaction Quality variable of 0.986 , including the very high reliability category. The reliability value of the composite Visual Quality variable was 0.686, including the reliability category, while the moderating model for the use intensity variable with the Visual Quality variable was 0.977 , including the very high reliability category. The reliability value in this study, indicated by the reliability of the composite and Croncbach's alpha, has varying reliability according to their respective value range categories, so that the data collected can be used for hypothesis testing.

\section{Hypothesis Testing}

Hypothesis testing is done to answer the problems posed in this study, using the results of the data analysis carried out. Hypothesis testing is carried out according to the research 
The $6^{\text {th }}$ International Seminar on Science and Technology (ISST) 2020

July $25^{\text {th }} 2020$, Institut Teknologi Sepuluh Nopember, Surabaya, Indonesia

Table 1.

Average variances extracted (AVE)

\begin{tabular}{cccccccccc}
\hline \hline UQ & IQ & SIQ & VQ & US & IP & IP*UQ & IP*IQ & IP*SIQ & IP*VQ \\
\hline 0.506 & 0.561 & 0.558 & 0.761 & 0.575 & 0.728 & 0.816 & 0.828 & 0.816 & 0.898 \\
\hline \hline
\end{tabular}

Table 2 .

Reliability Range

\begin{tabular}{ccc}
\hline \hline Nilai $\mathrm{r}$ & Keterangan \\
\hline $\mathrm{r}>0.90$ & Very high reliability \\
$\mathrm{r}>0.80$ & high reliability \\
$\mathrm{r}>0.70$ & Reliability is sufficient \\
$\mathrm{r}>0.60$ & Medium reliability \\
$\mathrm{r}>0.50$ & Low reliability \\
$\mathrm{r}<0.40$ & Very low reliability \\
\hline \hline
\end{tabular}

Table 3.

Reliability Calculation Results

\begin{tabular}{|c|c|c|c|c|c|c|c|c|c|c|}
\hline Reliability & UQ & IQ & SIQ & VQ & US & IP & IP*UQ & IP*IQ & IP*SIQ & IP*VQ \\
\hline $\begin{array}{l}\text { Composite } \\
\text { reliability }\end{array}$ & 0.883 & 0.893 & 0.879 & 0.864 & 0.832 & 0.889 & 0.991 & 0.990 & 0.987 & 0.981 \\
\hline Category & $\begin{array}{l}\text { high } \\
\text { reliability }\end{array}$ & $\begin{array}{l}\text { high } \\
\text { reliability }\end{array}$ & $\begin{array}{l}\text { high } \\
\text { reliability }\end{array}$ & $\begin{array}{l}\text { high } \\
\text { reliability }\end{array}$ & $\begin{array}{l}\text { high } \\
\text { reliability }\end{array}$ & $\begin{array}{l}\text { high } \\
\text { reliability }\end{array}$ & $\begin{array}{l}\text { Very high } \\
\text { reliability }\end{array}$ & $\begin{array}{c}\text { Very } \\
\text { high } \\
\text { reliability }\end{array}$ & $\begin{array}{l}\text { Very high } \\
\text { reliability }\end{array}$ & $\begin{array}{c}\text { Very } \\
\text { high } \\
\text { reliability }\end{array}$ \\
\hline $\begin{array}{l}\text { cronbach's } \\
\text { alpha }\end{array}$ & 0.843 & 0.853 & 0.831 & 0.686 & 0.721 & 0.812 & 0.990 & 0.989 & 0.986 & 0.977 \\
\hline Category & $\begin{array}{l}\text { high } \\
\text { reliability }\end{array}$ & $\begin{array}{l}\text { high } \\
\text { reliability }\end{array}$ & $\begin{array}{l}\text { high } \\
\text { reliability }\end{array}$ & $\begin{array}{l}\text { Medium } \\
\text { reliability }\end{array}$ & $\begin{array}{l}\text { Reliability } \\
\text { is } \\
\text { sufficient }\end{array}$ & $\begin{array}{l}\text { high } \\
\text { reliability }\end{array}$ & $\begin{array}{l}\text { Very high } \\
\text { reliability }\end{array}$ & $\begin{array}{c}\text { Very } \\
\text { high } \\
\text { reliability }\end{array}$ & $\begin{array}{l}\text { Very high } \\
\text { reliability }\end{array}$ & $\begin{array}{c}\text { Very } \\
\text { high } \\
\text { reliability }\end{array}$ \\
\hline
\end{tabular}

framework carried out to analyze and test directly and indirectly between exogenous and endogenous variables with a moderation model. The significance level of this hypothesis testing is done by looking at the p-value in Table 4 .

Direct hypothesis testing is used to determine the direct effect of each exogenous variable on endogenous. The exogenous variables consist of Usability Quality (UQ), Information Quality (IQ), Service Interaction Quality (SIQ), and Visual Quality (VQ). While the endogenous variable is User Satisfaction (US). The results of direct hypothesis testing can be seen in Table 5 .

The calculation of the influence of the Information Quality (IQ) variable on User Satisfaction (US), shows that the more clearly the information provided or presented by the website manager pddikti.kemdikbud.go.id the higher the user satisfaction / User Satisfaction (US).

The calculation of the influence of the Service Interaction Quality (SIQ) variable on User Satisfaction (US), shows that the better the feedback or interactive services provided or presented by the website manager pddikti.kemdikbud.go.id, the higher user satisfaction (US).

The calculation of the influence of the Visual Quality (VQ) variable on User Satisfaction (US), shows that the more attractive the appearance that is given or presented by the website manager pddikti.kemdikbud.go.id, the higher the user satisfaction / User Satisfaction (US).

Hypothesis testing is indirectly used to determine the indirect effect of each exogenous variable on endogenous through moderating variables which can weaken or strengthen its effect on endogenous variables. Exogenous variables consist of Usability Quality (UQ), Information Quality (IQ), Service Interaction Quality (SIQ), Visual Quality (VQ), and as a moderating variable is the Intensity of Use variable. While the endogenous variable is User Satisfaction (US). The results of direct hypothesis testing can be seen in the Table 6 .
The calculation of the influence of the Usability Intensity variable as a moderating variable of Usability Quality (UQ) on User Satisfaction (US), shows that the intensity of using the pddikti.kemdikbud.go.id website services further strengthens user satisfaction or User Satisfaction (US) towards services in the form of Usability Quality (UQ). ) provided by the website manager pddikti.kemdikbud.go.id.

The calculation of the influence of the Use Intensity variable as a moderating variable of Information Quality (IQ) on User Satisfaction (US), shows that the intensity of using the pddikti.kemdikbud.go.id website service further strengthens user satisfaction or User Satisfaction (US) with services in the form of Information Quality (IQ) provided by the website manager pddikti.kemdikbud.go.id.

The calculation of the influence of the Use Intensity variable as a moderating variable of Service Interaction Quality (SIQ) on User Satisfaction (US), shows that the intensity of using the pddikti.kemdikbud.go.id website services further strengthens user satisfaction or User Satisfaction (US) for services in the form of Service Interaction Quality (SIQ) provided by the website manager pddikti.kemdikbud.go.id.

The calculation of the influence of the Use Intensity variable as a moderating variable of Visual Quality (VQ) on User Satisfaction (US), shows that the intensity of using the pddikti.kemdikbud.go.id website service further strengthens user satisfaction or User Satisfaction (US) towards services in the form of Visual Quality (VQ) provided by the website manager pddikti.kemdikbud.go.id.

Table 7 shows inner model testing is done to see the index of goodness or feasibility of the relationship between exogenous variables related to the assumptions. This is done for interpretation of the results of hypothesis testing so that it must have a proper goodness of fit.

The structural equation in Figure 3 shows that the P-Value of each variable is less than 0.05 . This means that the 
The $6^{\text {th }}$ International Seminar on Science and Technology (ISST) 2020

July $25^{\text {th }}$ 2020, Institut Teknologi Sepuluh Nopember, Surabaya, Indonesia

Table 4.

Significance Level Criteria

\begin{tabular}{cc}
\hline \hline $\mathrm{p}$ - value & Explanation \\
\hline $\mathrm{p}$-value $<0.01$ & High significant \\
$\mathrm{p}$-value $<0.05$ & Significant \\
$\mathrm{p}$-value $<0.10$ & Significantly low \\
\hline \hline
\end{tabular}

Table 5 .

Hypothesis test results

\begin{tabular}{|c|c|c|c|c|c|}
\hline \multirow{2}{*}{ No } & \multicolumn{2}{|c|}{$\begin{array}{c}\text { Relationship } \\
\text { Between Variables }\end{array}$} & \multirow{2}{*}{$\begin{array}{c}\text { Path } \\
\text { Coefficient } \\
\text { View } \\
\end{array}$} & \multirow{2}{*}{$\begin{array}{c}\text { P- } \\
\text { Value } \\
\text { View }\end{array}$} & \multirow{2}{*}{$\begin{array}{c}\text { Level of } \\
\text { Significance }\end{array}$} \\
\hline & Eksogen & Endogen & & & \\
\hline 1. & UQ & US & 0.201 & 0.030 & Significant \\
\hline 2. & IQ & US & 0.474 & $<0.001$ & $\begin{array}{l}\text { High } \\
\text { significant }\end{array}$ \\
\hline 3. & SIQ & US & 0.335 & $<0.001$ & $\begin{array}{l}\text { High } \\
\text { significant }\end{array}$ \\
\hline 4. & VQ & US & 0.493 & $<0.001$ & $\begin{array}{c}\text { High } \\
\text { significant }\end{array}$ \\
\hline
\end{tabular}

Table 6.

Indirect Hypothesis Test Results

\begin{tabular}{|c|c|c|c|c|c|}
\hline \multirow[b]{2}{*}{ No } & \multicolumn{2}{|c|}{$\begin{array}{l}\text { Relationship Between } \\
\text { Variables }\end{array}$} & \multirow{2}{*}{$\begin{array}{c}\text { Path } \\
\text { Coefficient } \\
\text { View } \\
\end{array}$} & \multirow{2}{*}{$\begin{array}{c}\text { P- } \\
\text { Value } \\
\text { View }\end{array}$} & \multirow{2}{*}{$\begin{array}{c}\text { Level of } \\
\text { Significance }\end{array}$} \\
\hline & Moderating & Endogen & & & \\
\hline 1. & IP*UQ & US & 0.468 & $<0.001$ & Moderation \\
\hline 2. & IP*IQ & US & 0.503 & $<0.001$ & Moderation \\
\hline 3. & IP*SIQ & US & 0.273 & 0.005 & Moderation \\
\hline 4. & IP*VQ & US & 0.374 & $<0.001$ & Moderation \\
\hline
\end{tabular}

structural equation in this study is significant and with an Rsquare value of 0.19 .

\section{CONCLUSION}

Information about levels of variables that have the strongest and lowest influence on user satisfaction or User Satisfaction. The level of influence of these variables can be seen in Table 8 .

Based on Table 8, it is known that the Usability Quality variable has the lowest significance value, namely the Path Coefficient value of 0.201 with a P-Value of 0.030 , compared to the significance value of other variables that affect User Satisfaction.

\section{REFERENCES}

[1] Agung, Gregorius. 2001. WAP (Wireless Application Protocol) Programming dengan WML. Panduan. Yogyakarta.

[2] Akbar, Yuzi. 2016. Hubungan Intensitas Mengakses Sosial Media Terhadap Perilaku Belajar Mata Pelajaran Produktif Pada Siswa Kelas XI Jasa Boga di SMK 3 Klaten. Skripsi Universitas Negeri Yogyakarta.

[3] Andarwati, S. R. \& Sankarto, B. S. (2005). Pemenuhan Kepuasan Penggunaan Internet Oleh Peneliti Badan Litbang Penelitian Bogor. Jurnal Perpustakaan Pertanian, 14 (1).

[4] Andreas B. Eisingerich dan Gaia Rubera. 2010. "Drivers of Brand Commitment: A Cross National Investigation", Journal of International Marketing, Vol. 18 No. 2

[5] Arikunto. 2006. Prosedur Penelitian Suatu Pendekatan Praktek. Jakarta : PT. Rineka Cipta

[6] Barnes and R. Vidgen, "WebQual: An Exploration of Web-site Quality." 1998

[7] Barnes, Stuart J and Richard T Vidgen. 2001. WebQual: An Exploration of Web Site Quality. Schoo of Management, University of Bath, Bath.

[8] Barnes, S. J., dan Vidgen, R.T. (2002). Assessing e-commerce quality with WebQual: An evaluation of the usability, informaton quality, and interaction quality on Internet bookstores. Journal of Electronic Cormerce Research.

[9] Bekti, Bintu Humairah. 2015. Mahir Membuat Website dengan Adobe Dreamweaver CS6, CSS dan JQuery. Yogyakarta: ANDI
Table 7.

Goodness of Fit Inner Model

\begin{tabular}{|c|c|c|c|c|}
\hline No & $\begin{array}{c}\text { Model Fit and } \\
\text { Quality } \\
\text { Indices } \\
\end{array}$ & Fit Criteria & $\begin{array}{c}\text { Analysis } \\
\text { Results }\end{array}$ & Explanation \\
\hline 1. & $\begin{array}{l}\text { Average path } \\
\text { coefficient } \\
\text { (APC) }\end{array}$ & $\mathrm{P}<0.001$ & $\begin{array}{c}0.390 \\
\mathrm{P}<0.001\end{array}$ & Good \\
\hline 2. & $\begin{array}{l}\text { Average R- } \\
\text { squared } \\
\text { (ARS) }\end{array}$ & $\mathrm{P}<0.001$ & $\begin{array}{c}0.186 \\
\mathrm{P}=0.020\end{array}$ & Good \\
\hline 3. & $\begin{array}{l}\text { Average } \\
\text { adjusted R- } \\
\text { squared } \\
\text { (AARS) }\end{array}$ & $\mathrm{P}<0.001$ & $\begin{array}{c}0.094 \\
\mathrm{P}=0.097\end{array}$ & Good \\
\hline 4. & $\begin{array}{l}\text { Average } \\
\text { block VIF } \\
\text { (AVIF) }\end{array}$ & $\begin{array}{c}\text { acceptable if } \\
<=5 \text {, ideally } \\
<=3.3\end{array}$ & 4.7002 & Acceptable \\
\hline 5. & $\begin{array}{l}\text { Average full } \\
\text { collinearity } \\
\text { VIF (AFVIF) }\end{array}$ & $\begin{array}{c}\text { acceptable if } \\
<=5 \text {, ideally } \\
<=3.3\end{array}$ & 3.8476 & Acceptable \\
\hline
\end{tabular}

Table 8 .

Relationship Between Variables

\begin{tabular}{|c|c|c|c|c|c|}
\hline \multirow[b]{2}{*}{ No } & \multicolumn{2}{|c|}{$\begin{array}{c}\text { Relationship } \\
\text { Between Variables }\end{array}$} & \multirow{2}{*}{$\begin{array}{c}\text { Path } \\
\text { Coefficient } \\
\text { View }\end{array}$} & \multirow{2}{*}{$\begin{array}{c}\text { P- } \\
\text { Value } \\
\text { View }\end{array}$} & \multirow{2}{*}{$\begin{array}{c}\text { Level of } \\
\text { Significance }\end{array}$} \\
\hline & Eksogen & Endogen & & & \\
\hline 1. & UQ & US & 0.201 & 0.030 & Significant \\
\hline 2. & IQ & US & 0.474 & $<0.001$ & $\begin{array}{l}\text { High } \\
\text { significant }\end{array}$ \\
\hline 3. & SIQ & US & 0.335 & $<0.001$ & $\begin{array}{c}\text { High } \\
\text { significant }\end{array}$ \\
\hline 4. & VQ & US & 0.493 & $<0.001$ & $\begin{array}{c}\text { High } \\
\text { significant }\end{array}$ \\
\hline
\end{tabular}

[10] Bressolles, G dan Durrieu, F. (2011). Service Quality, Customer Value and Satisfaction Relationship Revisited for Online Wine Website. In 6th AWBR International Conference. France.

[11] Chen, Y. T., dan Chou, T. Y. (2012). "Exploring the continuance intentions of consumers for B2C online shopping: Perspectives of fairness and trust". Online Information Review, Vol. 36(1), pp. 104125.

[12] Crosby, Philip .1996. Quality is still free: Making Quality Certain in Uncertain Times. McGraw-Hill.

[13] Crosby, Philip B. (1979). Quality is Free. New York: Mc-Graw Hill Book Inc

[14] Erickson. 2011. Hubungan Intensitas Mengakses Situs Jejaring Sosial dengan Kemampuan Interaksi Sosial pada Mahasiswa 2011 Fakultas Kedokteran UNS. Surakarta, Universitas Sebelas Maret Surakarta, Skripsi

[15] Fandy Tjiptono and Gregorius Chandra. 2007. Service, Quality Satisfaction. Andi Ofset. Yogyakarta.

[16] Fandy Tjiptono. 2012. Strategi Pemasaran, ed. 3, Yogyakarta, Andi.

[17] Ghozali, Imam. 2008. Aplikasi Analisis Multivariate dengan Program SPSS. Semarang: Badan Penerbit Universitas Diponegoro

[18] Hasan, L., 2014. Evaluating the Usability of Educational Websites Based on Students' Preferences of Design Characteristics. International Arab Journal of e-Technology, 3(3), pp.179-193.

[19] Hidayat, Rahmat. (2010). Cara Praktis Membangun Website Gratis : Pengertian Website. Jakarta : PT Elex Media Komputindo Kompas, Granedia

[20] Ismoyo, Bani Nugroho, et al. 2017. 'Service Quality Perception's Effect On Customer Satisfaction and Repurchase Intention'. Journal European Business and Management. Vol 3 No. 3 pp.37-46.

[21] Kartono, Kartini dan Gulo, Dali. 2003. Kamus Psikologi. Bandung: Pionir Jaya.

[22] Kim, Jiyoung., dan Lennon, Sharron J. (2013). Effects Of Reputation And Website Quality On Online Consumers' Emotion, Perceived Risk And Purchase Intention: Based On The Stimulus-OrganismResponse Model. Vol. 7 Issue: 1, 33-56. Journal of Research in Interactive Marketing.

[23] Lovelock, Christopher. dan Wirtz, Jochen. (2011). Service Marketing: People, Technology, Strategy7th Edition. New Jersey: Pearson.

[24] Masthori, A., Nugroho, H.A. \& Ferdiana, R. 2016. Penggunaan Metode Webqual Modifikasi dalam Evaluasi Kualitas Layanan Website Pemerintah Daerah The Use of Modified Webqual Method in 
The $6^{\text {th }}$ International Seminar on Science and Technology (ISST) 2020

July $25^{\text {th }} 2020$, Institut Teknologi Sepuluh Nopember, Surabaya, Indonesia

Evaluation of Website Service Quality of Local Government. Jurnal Pekommas, 1(1): 57-68

[25] Napitupulu, Darmawan Baginda. 2017. Evaluasi Kualitas Website Universitas XYZ Dengan Pendekatan Webqual oleh Pusat Penelitian Sistem Mutu dan Teknologi. Jurnal.

[26] Nurhayati, "Analisa Website Puslit Indonesia Dengan Menggunakan WebQual Untuk Pengukuran Kualitas Website," 1998.

[27] Olsina, Luis, e. a. (2006). Web Quality. Springer , 10.1007/3-54028218-1_4, 109-142.

[28] Parasuraman, valarie A. Zeithaml, Leornard. Berry, 1985, “A Conceptual Model of Service Quality and Implication for Future Research" (Journal of Marketing).

[29] Parasuraman, valarie A. Zeithmal, Leornard L. Berry, 1990, "Delivering Quality Service : Balancing Customer Perception and Expectations" (The Free Press).

[30] Pullinger, D., and A. Bailin. 2010. Reporting on progress: Central government websites 2009/10. Central Office of Information, London.

[31] Pratminingsih, Sri., et al. 2013. Factors Influencing Customer Loyalty Toward Online Shopping. International Journal of Trade, Economics and Finance, Vol. 4, No. 3, June 2013.

[32] Riduwan. (2005). Skala Pengukuran Variable Penelitian. Bandung : Alfabeta

[33] Saladin, Djaslim, 2003, "Intisari Pemasaran dan Unsur-unsur Pemasaran", Cetakan Ketiga, Bandung : Linda Karya

[34] Sugiyono. 2010. Metode Penelitian Pendidikan Pendekatan Kuantitatif, kualitatif, dan R\&D. Bandung: Alfabeta

[35] Sugiyono. (2017). Metode Penelitian Kuantitatif, Kualitatif, dan R\&D. Bandung : Alfabeta, CV

[36] Sekaran, Uma dan Roger Bougie, (2017), Metode Penelitian untuk Bisnis: Pendekatan Pengembangan-Keahlian, Edisi 6, Buku 1, Cetakan Kedua, Salemba Empat, Jakarta Selatan 12610.

[37] Shin JK, Chung KH, Oh JS, Lee CW.2013. "The Influence Of Site Quality On Repurchase Intention In Internet Shopping Through
Mediating Variable: Student Cases In South Korea. Manajemen 33 (3): 453-463.

[38] S. Monalisa, “Analisis Kualitas Layanan Website Terhadap Kepuasan Mahasiswa dengan Penerapan Metode WebQual ( Studi Kasus : UIN Suska Riau )", 2016.

[39] Tandon, U., Kiran, R. and Sah, A.N. 2017. "Analyzing Customer Satisfaction: Users Perspective Towards Online Shopping". Nankai Business Review International, Vol. 8 Issue: 3, pp.266-288

[40] Tandon, U., Kiran, R. and Sah, A.N. 2017. "Customer Satisfaction as Mediator Between Website Service Quality and Repurchase Intention". An Emerging Economy Case. Service Science 9 (2) : 106-120.

[41] Tse dan Wilton (1988). Kepuasan Pelanggan, jilid 2. Edisi ketiga. Klaten : PT. Indeks Kelompok Gramedia.

[42] Umi Narimawati. 2008. Metodologi Penelitian Kualitatif dan Kuantitatif, Teori danAplikasi. Bandung: Agung Media

[43] Warjiyono. and Mei Hellyana, Corie. 2018. PENGUKURAN KUALITAS WEBSITE PEMERINTAH DESA JAGALEMPENI MENGGUNAKAN METODE WEBQUAL 4.0.Jurnal Teknologi Informasi dan Ilmu Komputer Vol. 5, No. 2, Mei 2018, hlm. 139-146

[44] Wicaksono, B.L., Susanto, A., Winarno, W.W. (2012). Evaluasi Kualitas Layanan Website PUSDIKLAT BPK RI Menggunakan Metode Webqual Modifikasian dan Importance Perfomance Analysis. Media Ekonomi \& Teknologi Informasi, 19 (1), 21-34.

[45] Yan, P. \& Guo, J. 2010. The Research of Web Usability Design, Computer and Automation Engineering (ICCAE), pp.480-483. IEEE. USA.

[46] Zeithaml, Valirie A., \&, Mary Jo. (2003). Service Marketing Integrating Customer Focus Across The Firm. New York: McGrawHill Companies.

[47] Zhou, T., Lu, Y., \& Wang, B. (2009). The relative importance of website design quality and service quality in determining consumers' online repurchase behavior. InformationSystemsManagement,26(4),327337.https://doi.org/10.108 $0 / 10580530903245663$. 